\title{
El caso Ayotzinapa. Arte y derechos humanos
}

\section{The Case of Ayotzinapa: Art and Human Rights}

Artículo recibido el 3I de mayo de 2020; devuelto para revisión el 30 de noviembre de 2020; aceptado el 6 de abril de 202I; https://doi.org./IO.2220I/iie.I8703062e.202I.II9.2755

Blanca Gutiérrez Galindo Universidad Nacional Autónoma de México, Facultad de Artes y Diseño, gutierrezgalindo.blanca@gmail.com, https://orcid. org/oooo-0002-II $47-3458$

Líneas de investigación Las articulaciones entre arte, política, memoria y movimientos sociales.

Lines of research articulations of art, politics, memory and social movements.

Publicación más relevante "Las movilizaciones por Ayotzinapa: tres imágenes", Cuadernos Del CILHA, núm. 33 (2020): I4I-I65, https://revistas.uncu.edu.ar/ojs3/ index.php/cilha/article/view/3938.

Resumen La desaparición de 43 estudiantes de la Escuela Normal Rural "Raúl Isidro Burgos" de Ayotzinapa y el asesinato de seis personas más, la noche del 26 al 27 de septiembre de 2014 en Iguala, Guerrero, pusieron en evidencia la grave crisis de derechos humanos por la que atraviesa México y generaron una enorme solidaridad entre los artistas. El objetivo de este artículo, de acuerdo con la noción de litigio artístico de la abogada colombiana Yolanda Sierra, es explicar las piezas Papalotes, de Francisco Toledo, Nivel de confianza, de Rafael Lozano-Hemmer y Retratos de LEGO. Caso Ayotzinapa, de Ai Weiwei. Se mostrará que, articuladas a partir de las imágenes de los rostros de los estudiantes, estas piezas ejecutan acciones de reconocimiento y memoria que contribuyen a gestionar el duelo, imaginar formas diferentes de relación social entre los mexicanos y llamar la atención sobre el caso en el ámbito global.

Palabras clave Imágenes de desaparecidos; litigio artístico; duelo; memoria; imagen postpop.

Abstract The disappearance of 43 students at the Escuela Normal Rural (Rural Teacher-Training Institute) "Raúl Isidro Burgos" of Ayotzinapa and the murders of another six individuals, on the night of 26-27 September, 20I4, in Iguala, Guerrero, brought to light the appalling crisis of human rights which Mexico has been undergoing, and generated 
overwhelming solidarity among artists. Along the lines of Colombian lawyer Yolanda Sierra's notion of artistic litigation, this article sets out to explicate the works Papalotes (Kites) by Francisco Toledo, Nivel de Confianza (Confidence Level) by Rafael Lozano-Hemmer and Retratos de LEGO. Caso Ayotzinapa (LEgo Portraits: the Ayotzinapa Case) by Ai Weiwei. The article will show that, elaborated from the images of the faces of the students, these works perform actions of recognition and memory that help to deal with mourning, while conceiving of different forms of social relations among Mexicans and drawing attention to the case in the global arena.

Keywords Images of the disappeared; artistic litigation; mourning; memory; postpop images.

\section{3 estudiantes desaparecidos:}

I. Abel García Hernández

2. Abelardo Vázquez Peniten

3. Adán Abraján de la Cruz

4. Antonio Santana Maestro

5. Alexander Mora Venancio

6. Benjamín Ascencio Bautista

7. Bernardo Flores Alcaraz

8. Carlos Iván Ramírez Villarreal

9. Carlos Lorenzo Hernández Muñoz

Io. César Manuel González Hernández

II. Christian Alfonso Rodríguez Telumbre

I2. Christian Tomás Colón Garnica

13. Cutberto Ortiz Ramos

I4. Dorian González Parral

15. Emiliano Alen Gaspar de la Cruz

I6. Everardo Rodríguez Bello

17. Felipe Arnulfo Rosas

I8. Giovanni Galindes Guerrero

I9. Israel Caballero Sánchez

20. Israel Jacinto Lugardo

2I. Jesús Jovany Rodríguez Tlatempa

22. Jhosivani Guerrero de la Cruz

23. Jonás Trujillo González

24. Jorge Álvarez Nava

25. Jorge Aníbal Cruz Mendoza
26. Jorge Antonio Tizapa Legideño

27. Jorge Luis González Parral

28. José Ángel Campos Cantor

29. José Ángel Navarrete González

30. José Eduardo Bartolo Tlatempa

3I. José Luis Luna Torres

32. Julio César López Patolzin

33. Leonel Castro Abarca

34. Luis Ángel Abarca Carrillo

35. Luis Ángel Francisco Arzola

36. Magdaleno Rubén Lauro Villegas

37. Marcial Pablo Baranda

38. Marco Antonio Gómez Molina

39. Martín Getsemany Sánchez García

40. Mauricio Ortega Valerio

4I. Miguel Ángel Hernández Martínez

42. Miguel Ángel Mendoza Zacarías

43. Saúl Bruno García

\section{6 personas asesinadas:}

I. Julio César Mondragón Fontes, estudiante.

2. Daniel Solís Gallardo, estudiante.

3. Julio César Ramírez Nava, estudiante.

4. David Josué García Evangelista, futbolista.

5. Víctor Manuel Lugo Ortiz, chofer.

6. Blanca Montiel Sánchez, pasajera de un taxi. 
https://doi.org./10.22201/iie.18703062e.2021.119.2755

\author{
BLANCA GUTIÉRREZ GALINDO \\ FACULTAD DE ARTES Y DISEÑO, UNAM
}

\title{
El caso Ayotzinapa. Arte y derechos humanos
}

$\mathrm{E}$ ntre un número mayor de obras, proyectos, intervenciones y performativos artísticos derivados de las movilizaciones generadas por la desaparición de los 43 estudiantes de la Escuela Normal "Raúl Isidro Burgos" de Ayotzinapa, en este texto me propongo analizar las piezas Papalotes (20I4), de Francisco Toledo, Nivel de confianza (2015), de Rafael Lozano-Hemmer y Retratos de LEGO. Caso Ayotzinapa (2019) de Ai Weiwei con el objetivo de mostrar las formas como se insertan en la defensa por los derechos humanos. Para ello partiré de las ideas de la jurista colombiana Yolanda Sierra León, quien ha establecido diversas nociones importantes para abordar las relaciones entre arte y derechos humanos; en particular retomaré la noción de litigo artístico que Sierra León explica como un campo de trabajo de investigación en el ámbito de los derechos culturales y en específico de la reparación simbólica. ${ }^{I}$ La noción de litigo artístico se refiere

al amplio catálogo de obras o piezas de arte, de autoría de profesión o de oficio que se manifiestan en campos como el cine, teatro, literatura, artes plásticas, performance y que [...] buscan poner de manifiesto una situación concreta de vulneración de los derechos humanos, ya sea de una víctima, un grupo de víctimas o incluso vulneraciones propias de un periodo de represión concreto. ${ }^{2}$

I. Todo ello en el Departamento de Derechos de la Universidad de Externado de Colombia. Yolanda Sierra León, Reparación simbólica. Jurisprudencia, cantos y tejido, ed. Yolanda Sierra León (Bogotá: Universidad de Externado Colombia, 20I8), II.

2. Sierra León, Reparación simbólica, 30. El par conceptual del litigo artístico es el litigio estético, "definido como un mecanismo de defensa de los derechos humanos, utilizado por 
Si bien esta idea, al igual que otras importantes abordadas por Sierra León, ha sido elaborada en el contexto jurídico colombiano, resulta sumamente productiva para avanzar en el estudio de lo que, sin duda, es una de las vertientes que hoy día definen las relaciones entre arte y movimientos sociales, y entre arte y política: la de la defensa de los derechos fundamentales y la reparación simbólica "como campo propio de la reparación integral a las víctimas de graves violaciones a los derechos humanos"3 que abarca "desde derechos autónomos como la verdad, la dignidad y la memoria, hasta garantías de satisfacción y no repetición". ${ }^{4}$

Desde diferentes perspectivas, las piezas que analizaré en este texto se inscriben en los horizontes del litigio artístico porque comparten el hecho de haber sido realizadas por artistas autónomos e independientes, es decir, que no han sufrido directamente los hechos que tematizan en sus obras, ${ }^{5}$ y quienes por voluntad propia decidieron "exponer en la palestra pública una situación de impunidad, anormalidad, injusticia, indiferencia social y estatal". ${ }^{6}$ Estas piezas se refieren al delito de desaparición forzada contra los 43 estudiantes y el asesinato de otros tres; buscan dignificarlos; incorporan los derechos de verdad y memoria; se sitúan del lado de los familiares y pretenden apoyar en el trámite seguido a la tragedia; ${ }^{7}$ asimismo, buscan un efecto sensibilizador que genere empatía y solidaridad y permita al público acercarse a la realidad atroz del caso Ayotzinapa. ${ }^{8}$

El criterio de selección de las piezas fue el uso que en cada una se hace de las imágenes de los rostros de los 43 estudiantes, toda vez que las imágenes de los rostros de los desaparecidos representan un elemento clave en las batallas de los familiares y constituyen un factor central de las luchas políticas contra la desaparición forzada. Como afirma Ana Longoni, junto con las siluetas, las fotos de miles de rostros en pancartas enarboladas en marchas y movilizaciones por los derechos humanos son los referentes más importantes de esas batallas. ${ }^{9}$

las comunidades de víctimas, mediante el uso del arte, las prácticas culturales o el patrimonio cultural", 33 .

3. Sierra León, Reparación simbólica, $\mathrm{I} 2$.

4. Sierra León, Reparación simbólica, I3.

5. Sierra León, Reparación simbólica, 31.

6. Sierra León, Reparación simbólica, 30-31.

7. Sierra León, Reparación simbólica, 33.

8. Yolanda Sierra León, "Relaciones entre arte y Derechos Humanos", Revista de Derecho del Estado, núm. 32 (enero-junio de 20I4): 90-93, https://revistas.uexternado.edu.co/index.php/ derest/article/ view/3815/4008 (consultada el I6 de mayo de 2019).

9. Ana Longoni, "Fotos y siluetas: dos estrategias contrastantes en la representación de los 


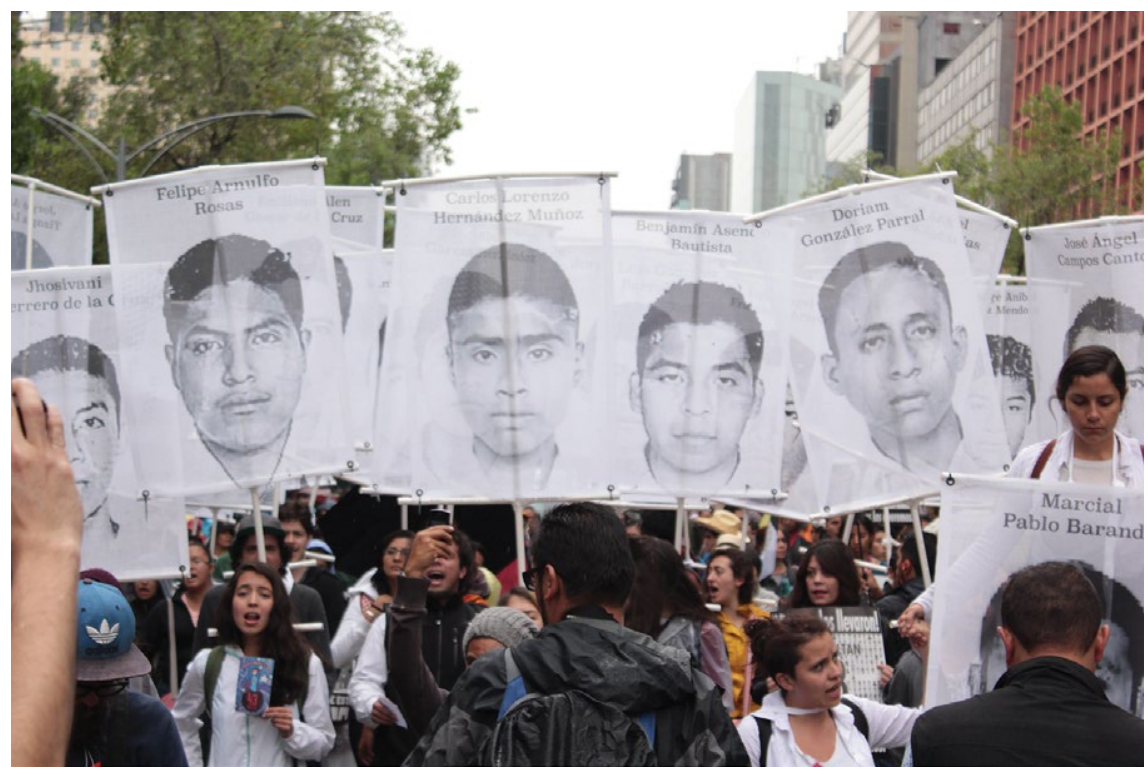

I. "Marcha aniversario Ayotzinapa". Foto: Comisión Interamericana de Derechos Humanos CC BY 2.0.

Al hacer uso de las imágenes de los rostros de los estudiantes, los artistas se apropian de un artefacto privilegiado de las movilizaciones sociales y comparten con éstas la exigencia del reconocimiento moral, social y jurídico ${ }^{\text {Io }}$ de los estudiantes (fig. I). De tal suerte, explicaré el papel de esas imágenes en la articulación del litigio artístico y sus vínculos con esas movilizaciones.

\section{Papalotes}

El 28 de diciembre de 2014 el artista Francisco Toledo elaboró 43 papalotes en tela color blanco en los cuales estampó con esténcil los rostros de los estudiantes desaparecidos enmarcados en una figura de un diamante. Las piezas

desaparecidos", en Los desaparecidos en la Argentina. Memorias, representaciones e ideas (19832008), ed. Emilio Crenzel (Buenos Aires: Biblos, 2010), 43-63.

Io. Axel Honneth, La lucha por el reconocimiento. Por una gramática moral de los conflictos sociales (Barcelona: Crítica, 1997). 
https://doi.org./10.22201/iie.18703062e.2021.119.2755

80 BLANCA GUTIÉRREZ GALINDO

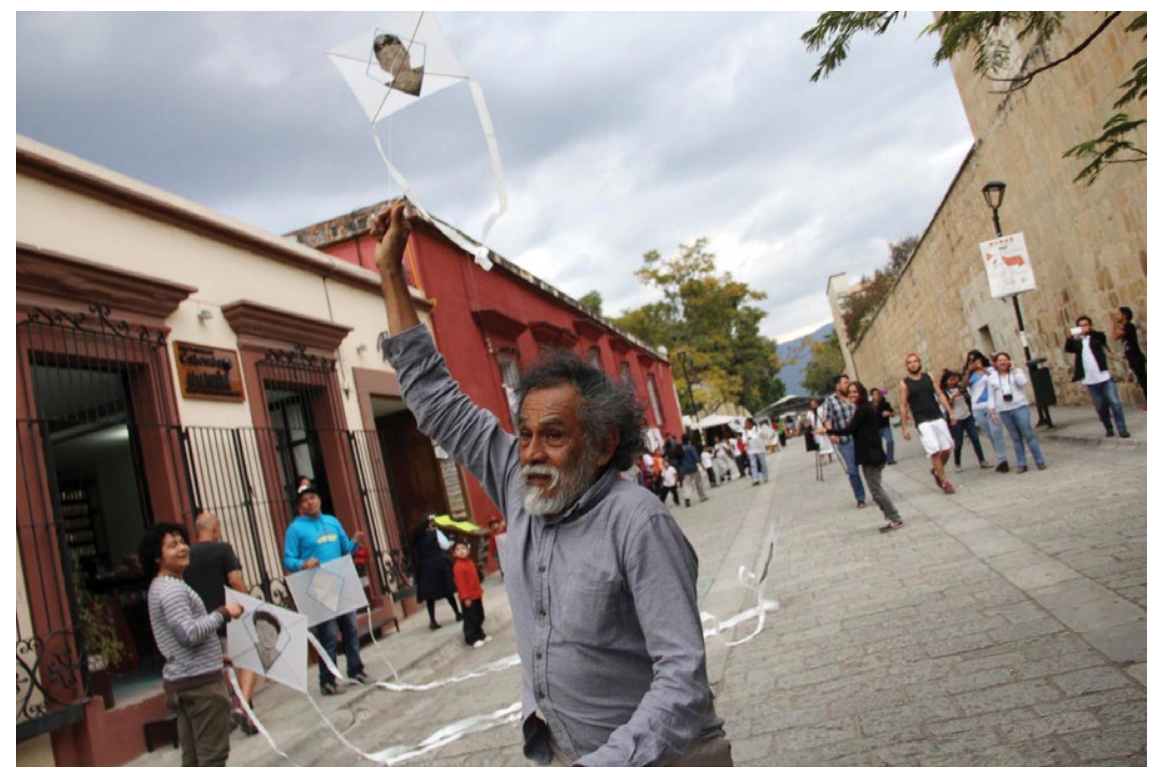

2. Francisco Toledo vuela un papalote en homenaje a los 43 de Ayotzinapa el is de diciembre de 20I4. Foto: Arturo Pérez Alfonso, Cuartoscuro.

fueron realizadas en colaboración con trabajadores del Taller Arte y Papel de San Agustín Etla, alumnos de primaria de distintas escuelas de la ciudad y asiduos del Instituto de Artes Gráficas de Oaxaca. Los papalotes se echaron a volar en el andador turístico de la ciudad de Oaxaca en tres ocasiones (figs. 2 y 3 ).

Estas acciones se efectuaron en los momentos en que los familiares de los estudiantes comenzaban a buscar sus restos en fosas clandestinas, y después de que, el 7 de noviembre, el ex procurador de la República, Jesús Murillo Karam, diera a conocer lo que llamó la "verdad histórica" sobre los hechos, a saber, que al confundirlos con integrantes de un cártel rival, la policía municipal de Iguala habría entregado a los 43 normalistas al grupo de narcotraficantes Los Rojos, quienes tras asesinarlos habrían quemado sus cuerpos en una gran fogata en el basurero de Cocula y esparcido sus cenizas en el río San Juan. Astrid Adriana Pozos Barcelata afirma que los familiares iniciaron la búsqueda primero en las inmediaciones de Iguala y luego en otros lugares del país porque la violencia ejercida sobre Julio César Mondragón y las numerosas desapariciones ocurridas en Guerrero, les hicieron pensar que los cuerpos podrían estar 


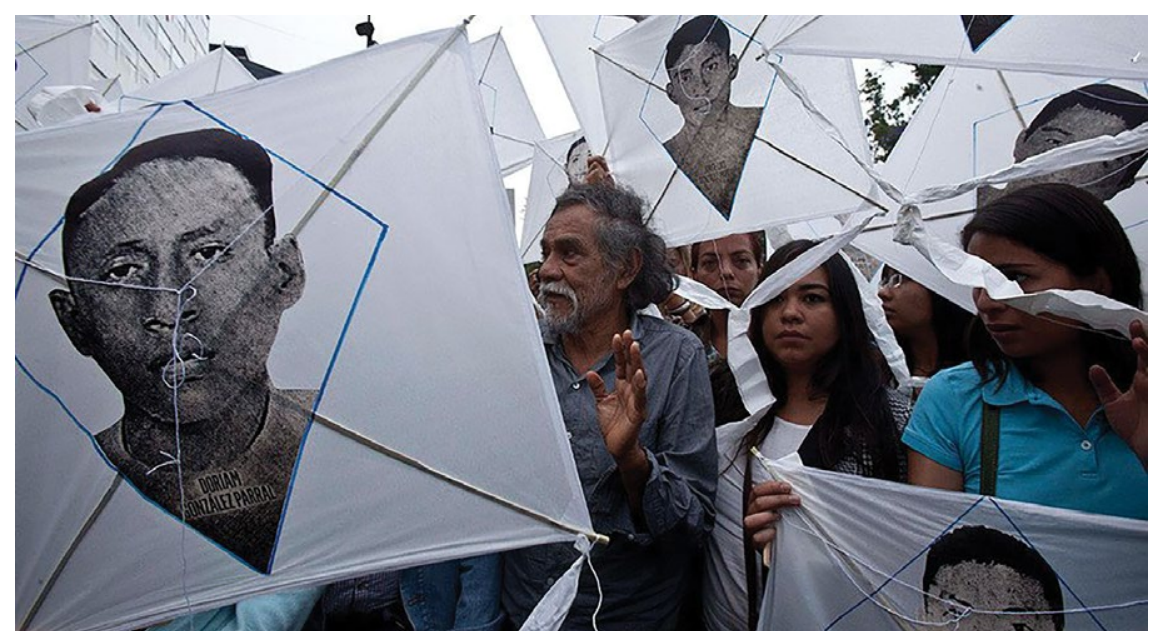

3. Francisco Toledo, Papalotes, 20I4, Oaxaca de Juárez, Oaxaca, Cuartoscuro.

en alguna de las numerosas fosas clandestinas ${ }^{\text {II }}$ que se habían multiplicado desde la puesta en marcha de la "guerra contra el narcotráfico" en 2006.

Papalotes fue la contribución de Toledo a esa búsqueda. En las acciones efectuadas en Oaxaca, y con posterioridad en las marchas y movilizaciones, y en su presentación en museos y centros culturales, los papalotes con las imágenes de los rostros de los normalistas fueron emplazados en diferentes relaciones con el espacio y los cuerpos, de modo que sus posibilidades de interpretación son diversas tal y como trataré de mostrar en los párrafos siguientes.

Portadas de manera individual por los participantes en las movilizaciones, marchas y concentraciones, las imágenes de los rostros de los normalistas impresas en los papalotes tienen un valor de verdad, un valor simbólico y un valor afectivo que es también agentivo. En efecto, son prueba de su existencia y de la existencia de la desaparición forzada en el país, y su exhibición en el es-

II. Astrid Adriana Pozos Barcelata afirma que a menos de is días de la desaparición de los estudiantes llegaron 500 miembros de la Unión de Pueblos y Organizaciones del Estado de Guerrero (UPOEG), que también tenían miembros desaparecidos en la región, con la consigna de no abandonar Iguala hasta no encontrar vivos o muertos a los desaparecidos. "Le Corps absent comme sujet politique: le processus de construction des disparitions forcées au Mexique comme un problème d'action publique (1969-2018)", tesis de doctorado en Ciencias Políticas (Québec: Université du Québec, 2018), 334. 
pacio público materializa el conflicto de la ciudadanía con la respuesta de los diferentes niveles de gobierno a la tragedia. Al mismo tiempo, poseen un valor simbólico que está definido por sus usos, que van de la forma en la cual las madres y padres las portan en cada una de sus apariciones públicas hasta la confección de vestidos y su ubicación en los mesabancos de las escuelas. ${ }^{12}$ Así, los papalotes han pasado a formar parte del imaginario visual de las luchas políticas contra la desaparición forzada que han convertido las imágenes de los rostros en uno de sus artefactos centrales. ${ }^{13}$ La dimensión afectiva de estas imágenes cohesiona la lucha e impacta a la población al apelar a su empatía o desafiar su percepción, y afecta su conciencia y su propia capacidad para actuar sobre los acontecimientos.

Ahora bien, en las acciones callejeras en las cuales Francisco Toledo, acompañado de niños, ha echado a volar Papalotes se agrega otra capa de sentido estrechamente vinculada con la dimensión afectiva de las imágenes. De acuerdo con las declaraciones del propio Francisco Toledo, cuando realizó los papalotes los estudiantes podrían estar muertos: "Si se les busca bajo tierra, también hay que buscarlos en los aires. Confío en que sigan con vida". ${ }^{14} \mathrm{El}$ artista explicó que la idea de imprimir los rostros en las superficies del armazón que sería elevada por el aire proviene de una tradición antigua que se practica en Juchitán, Oaxaca, de donde era originario el artista, y en la cual la gente los utiliza para atraer las almas de las personas que han fallecido, de modo que el día de los

I2. Los usos de las fotografías de los desaparecidos van desde coserlas a la propia vestimenta, imprimir sus imágenes en prendas de vestir y portarlas con las dos manos, hasta presentar el propio cuerpo para la confección de siluetas. Véase Ludmila Da Silva Catela, "Lo invisible revelado. El uso de fotografías como (re) presentación de la desaparición de personas en Argentina”, en El pasado que miramos. Memoria e imagen en la historia reciente, comps. Claudia Feld y Mor Stites (Buenos Aires: Paidós: 2007), 243-247; Ana Longoni y Gustavo Bruzzone, El Siluetazo (Buenos Aires: Adriana Hidalgo, 2008); Diana Taylor, El archivo y el repertorio. El cuerpo y la memoria cultural en las Américas (Santiago de Chile: Ediciones Universidad Alberto Hurtado, 20I5). En el caso específico de las movilizaciones por Ayotzinapa véase Cristina Híjar González, "El retrato y el numeral 43: artefactos político-estéticos en la acción colectiva por Ayotzinapa en México", tesis de maestría en Comunicación y Política (Ciudad de México: Universidad Autónoma Metropolitana-Unidad Xochimilco, 2016).

13. Victoria Langland, "Fotografía y memoria", en Escrituras, imágenes y escenarios ante la represión, comps. Elizabeth Jelin y Ana Longoni (Madrid: Siglo XXI Editores, 2005), 87.

I4. Luis Hernández Navarro, "Un papalote para Toledo", La Jornada, 6 de septiembre de 2019, https://eloficiodehistoriar.com.mx/2019/o9/o6/un-papalote-para-toledo/ (consultado el 2I de mayo de 2020). 
muertos, el 2 de noviembre, los difuntos bajan a través del hilo de los cometas a tomar el alimento y luego vuelven a volar. ${ }^{15}$ Se trata de una construcción de sentido que, en esa región del Istmo de Tehuantepec, permite a sus habitantes tramitar la pérdida de los seres queridos. En consecuencia, se puede afirmar que, en las acciones ejecutadas por Toledo en el espacio público, las imágenes de los rostros se insertan en el mundo de los rituales funerarios, de modo que Papalotes puede ser entendida como una herramienta para el procesamiento del duelo por la desaparición de los estudiantes.

Esas imágenes desempeñan un papel semejante al de las usadas en los ritos funerarios antiguos, cuando servían para dotar de vida a los difuntos y fijar un lugar para ellos en orden a reintegrarlos dentro de la comunidad. ${ }^{16}$ Papalotes señala un lugar para los 43, y ese lugar es el cielo, donde, de acuerdo con la tradición católica moran las almas de los justos y los virtuosos, donde gozan de la presencia de Dios después de muertos. De manera semejante a la operación de reconocimiento y restitución realizada por Paul Celan para los judíos desaparecidos en los crematorios de los campos de concentración nazis en su Fuga de muerte, en donde a la letra escribe "Cavamos una tumba en el aire donde no hay opresión", Toledo ejecuta una acción ritual que, luego de la criminalización de los estudiantes por parte de las autoridades cuando intentaron vincularlos con grupos de narcotraficantes ${ }^{17} \mathrm{y}$ con grupos guerrilleros ${ }^{18}$ les restituye su lugar en la comunidad.

Así, en las acciones callejeras donde se elevan los cometas o se fijan en los muros y ventanas del espacio público, lo que se ejecuta es una puesta en escena cultual en donde las imágenes de los estudiantes son aclamadas dentro de la comunidad. Se puede decir, así, que Papalotes forma parte de las puestas en escena cultuales ${ }^{19}$ que permiten extraer el cuerpo simbólico de los jóvenes

I5. Lizbeth Flores, "Toledo y los papalotes que voló por los 43 normalistas", El Universal, 27 de septiembre de 2019, https://oaxaca.eluniversal.com.mx/sociedad/27-09-2019/toledo-y-los-papalotes-que-volo-por-los-43-normalistas (consultado el I6 de enero de 2020).

16. Hans Belting, Antropología de la imagen (Madrid: Katz, 2010), I8I.

17. Un ejemplo de esto es la película La noche de Iguala (2015), escrita por el columnista Jorge Fernández Menéndez y producida por TV Azteca, en la cual se afirma que la tortura y el desollamiento de Julio César Mondragón se debió a que el normalista era jefe narcotraficante del grupo Los Rojos. En ella se explica lo ocurrido aquella noche avalando la versión del entonces procurador general de la república, Jesús Murillo Karam.

I8. Raymundo Riva Palacio, “Ayotzinapa: 'Los Rojos' y la guerrilla”, El Financiero, i3 de noviembre de 2015, https://www.elfinanciero.com.mx/opinion/raymundo-riva-palacio/ayotzinapa-los-rojos-y-la-guerrilla (consultado el ro de agosto de 2018).

19. Hans Belting, Imagen y culto (Madrid: Akal, 2009), 23. 
estudiantes del basurero de Cocula y de las fosas clandestinas para restituir su presencia entre los suyos, en el mundo de los vivos.

Es importante señalar que en esas puestas en escena las imágenes no imitan los rostros de los estudiantes, sino que, mientras que sus cuerpos desaparecen materialmente, las imágenes llenan su ausencia entre sus deudos; por ello son imágenes para los vivos. ${ }^{20}$ Una función semejante desempeñan las imágenes portadas por las madres y los padres de los normalistas en cada una de sus apariciones públicas porque para ellos las imágenes de los rostros "son" los estudiantes. De tal suerte, y de acuerdo con Hans Belting, ${ }^{21}$ los papalotes formarían parte de aquel conjunto funerario conformado por máscaras, momias, estelas y urnas con las cuales desde la antigüedad se suele suplantar a los ausentes. Me parece que ése es el sentido de su exhibición suspendidas del techo en el Museo de Memoria y Tolerancia en 2015 y en el Museo de Arte Contemporáneo de la UNAM en 2018 (fig. 4).

Ahora bien, en Papalotes, las imágenes de los rostros tienen también una función memorial pues están ahí para celebrar el recuerdo de los que no están. Tal es su papel cuando los papalotes se exhiben en conjuntos ordenados en secuencias que forman paneles o rejillas tanto en el espacio público o en museos y centros culturales; por ejemplo, en el Centro Cultural Independiente "El Ocote" de Juchitán, Oaxaca en 2016. A esa función pueden subsumirse cuando se exhiben en una secuencia ininterrumpida en un manto adosado a la pared como en el Instituto de Artes Gráficas de Oaxaca (IAGo) en 2019 (fig. 5), donde pareciera que, igual que el santo sudario en el que se imprimieron el cuerpo y la cara de Cristo después de su muerte, esas imágenes pertenecerían a la categoría de imágenes "no fabricadas". ${ }^{22}$ En ellas la tela es simultáneamente medio de contacto y medio visual: en el primer caso testimonia la realidad de un cuerpo y en la segunda muestra un rostro como imagen. ${ }^{23}$ En su calidad de "imágenes no fabricadas" estas imágenes parecerían habitadas y animadas, como las imágenes milagrosas de los dioses antiguos.

Así, los significados materializados en Papalotes inciden en la causa política sintetizada en la consigna "Vivos se los llevaron, vivos los queremos", que reclama al Estado la responsabilidad de dar cuenta del paradero de los estu-

20. Belting, Antropología de la imagen, I8I.

2I. Belting, Antropología de la imagen, 183 .

22. Hans Belting, La Vraie image. Croire aux images? (París: Gallimard, 2005), 85.

23. Belting, La Vraie image, 80. 


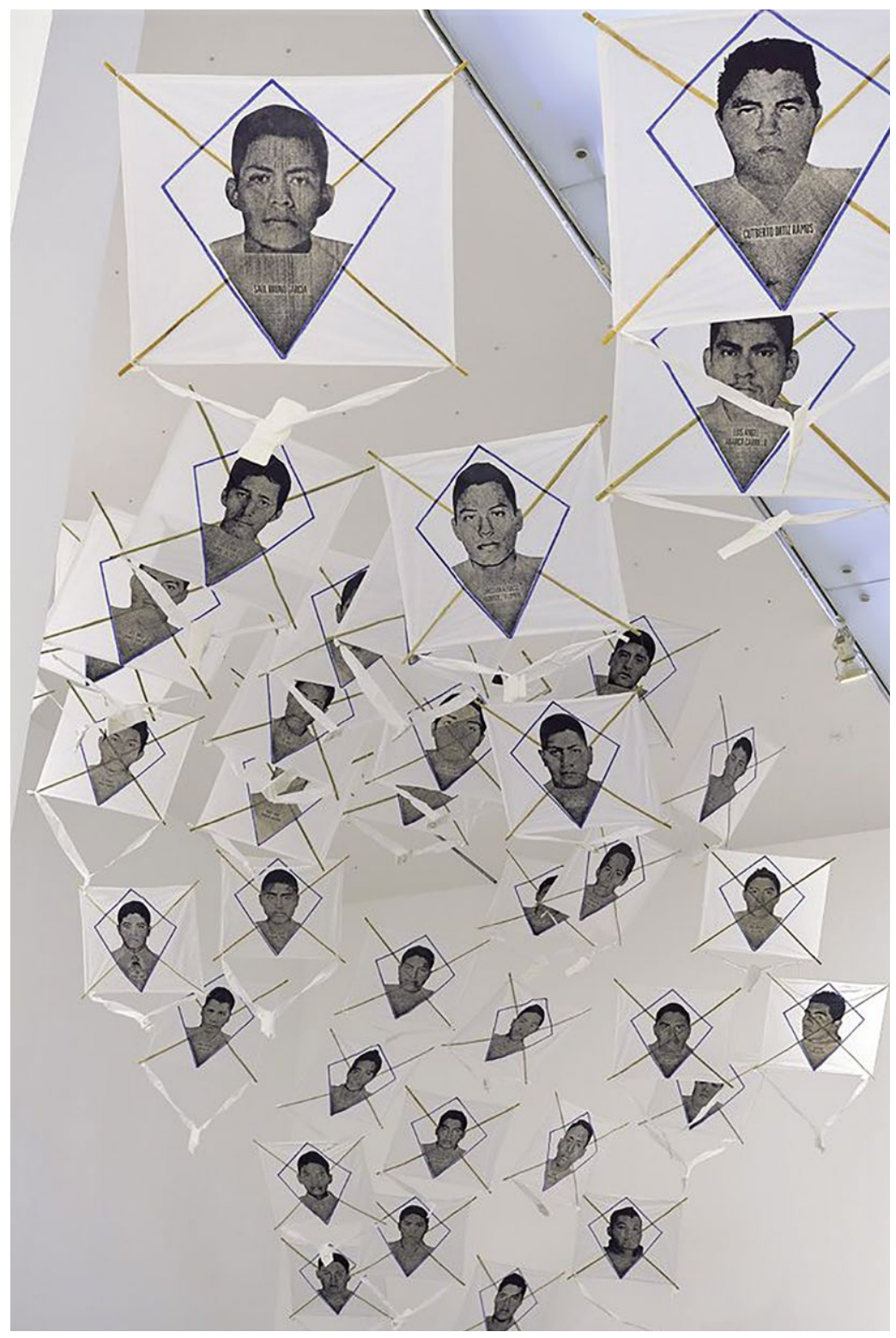

4. Francisco Toledo, Papalotes, exposición "Sublevaciones", Museo Universitario Arte Contemporáneo, Ciudad de México. Foto cortesía MUAC. 
https://doi.org./10.22201/iie.18703062e.2021.119.2755

86

BLANCA GUTIÉRREZ GALINDO

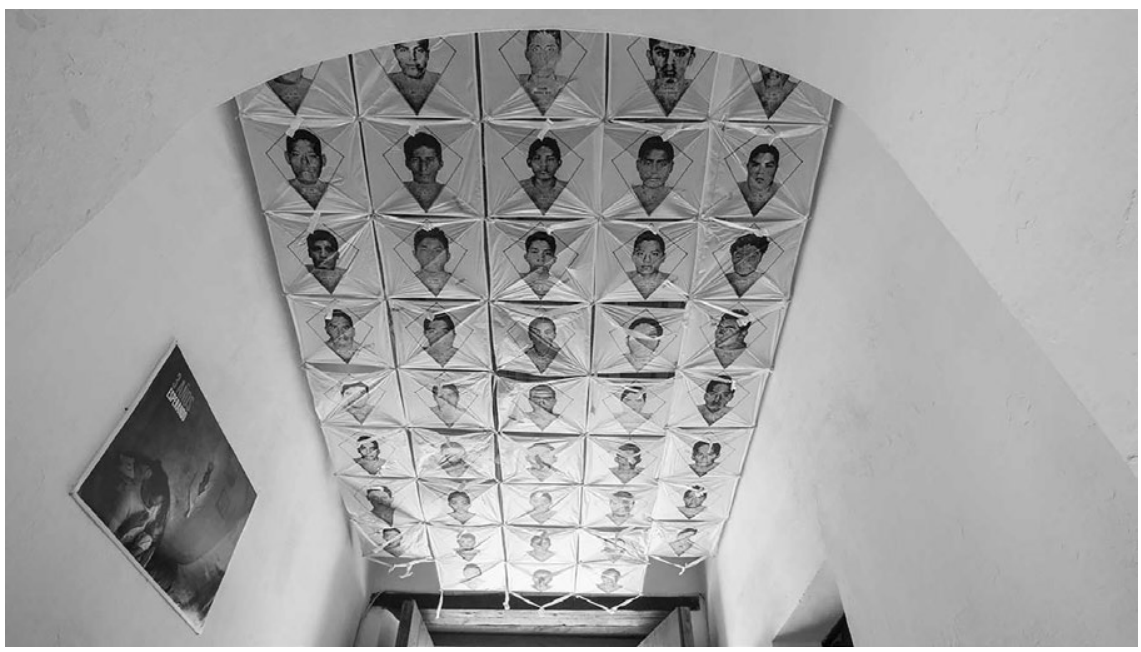

5. Francisco Toledo, Papalotes, 20I4, Instituto de Artes Gráficas de Oaxaca, Oaxaca, 20I9. Foto:

(C) Fernando Luna Arce, 25 de octubre de 2017, Oaxaca de Juárez, Oaxaca, México.

diantes y llevar a cabo procesos de justicia, y también en la causa humanitaria que permitiría a los familiares y a la sociedad, si eso fuera posible, cerrar el ciclo de existencia de las persona desaparecidas al ensayar el trámite del duelo que pudiera ayudar a superar "la ausencia", "el hueco", "el vacío", en suma "la quiebra del sentido que deja la desaparición". ${ }^{4}$ Por esa vía, al solidarizarse con los afectados ${ }^{25} \mathrm{y}$ al incorporar tradiciones relacionadas con los procesos de duelo, la pieza ubica el problema de la desaparición de los estudiantes en la esfera pública y apela a la empatía. ${ }^{26}$ Además, y de manera importante, Papalotes le restituye al arte una función dentro de la comunidad.

\section{Nivel de confianza}

Yolanda Sierra León establece que las contribuciones de las obras artísticas que tematizan el problema de las violaciones al derecho humanitario no

24. Gabriel Gatti, "Las narrativas del detenido-desaparecido (o de los problemas de la representación ante catástrofes sociales)", Confines, núms. 2 y 4 (diciembre de 2006), 29.

25. Sierra León, Reparación simbólica, 32.

26. Sierra León, Reparación simbólica, 33. 
necesariamente generan cambios en las relaciones de dominación y poder que crean la vulnerabilidad, pero sí tienen la capacidad de "influir los discursos, las subjetividades, los modos de interrelación social, los imaginarios sociales, las representaciones del otro y las identidades, de manera tal que se incida positivamente sobre la condición de vulnerabilidad de las víctimas, y se contribuya a que las causas de esa vulnerabilidad sean visibles". ${ }^{27}$ Considero que Nivel de confianza de Rafael Lozano-Hemmer puede pensarse en ese horizonte.

El 26 de marzo de 2015 Lozano-Hemmer activó Nivel de confianza, una pieza basada en los algoritmos usados por los sistemas policiacos para identificar a criminales a partir de una base de datos de individuos sospechosos que funciona en la interacción de los espectadores con las imágenes en blanco y negro de los rostros de los 43 estudiantes. La pieza está conformada por un software y un instructivo que pueden ser descargados gratuitamente por personas o instituciones para proyectarla con dispositivos básicos como una computadora, una webcam y una pantalla. Una vez que los usuarios entran en contacto con ella, la tecnología biométrica detecta sus rasgos faciales al tiempo que establece coincidencias con uno o varios de los rostros de los estudiantes, y la pantalla muestra en tiempo real el "parecido" entre ambas personas traducido en porcentajes (fig. 6). De ahí el título de la pieza, que alude a la idea del nivel de confianza en estadística, que indica qué tan probable es que el parámetro de población esté dentro del llamado intervalo de confianza. Según palabras del artista, el título también alude "a la desconfianza que genera la ineptitud de nuestros gobernantes" ${ }^{28}$

Nivel de confianza se activó de manera simultánea en el Departamento de Arte y Gestión Cultural de la Universidad Autónoma de Aguascalientes, en la Galería Guy Bärtschi de Ginebra y en la galería fora de la Universidad de Concordia en Montreal. Poco después se presentó en el Centro Multimedia del Centro Nacional de las Artes en la Ciudad de México y en el Museo Universitario de Arte Contemporáneo de la UNAM. En este último recinto estuvo ubicada en el espacio que antecede a la entrada principal, por lo que cualquier persona que transitara por ahí podía encontrarse con ella. Desde entonces ha sido presentada en numerosos museos, universidades y centros culturales.

27. Sierra León, "Relaciones entre el arte y los derechos humanos", 90.

28. Andrea G. Cuevas, "Nivel de confianza, entrevista de Andrea G. Cuevas con Rafael Lozano-Hemmer", 20I7, https://nanopdf.com/download/nivel-de-confianza_pdf (consultado el II de diciembre de 2019). 
https://doi.org./10.22201/iie.18703062e.2021.119.2755

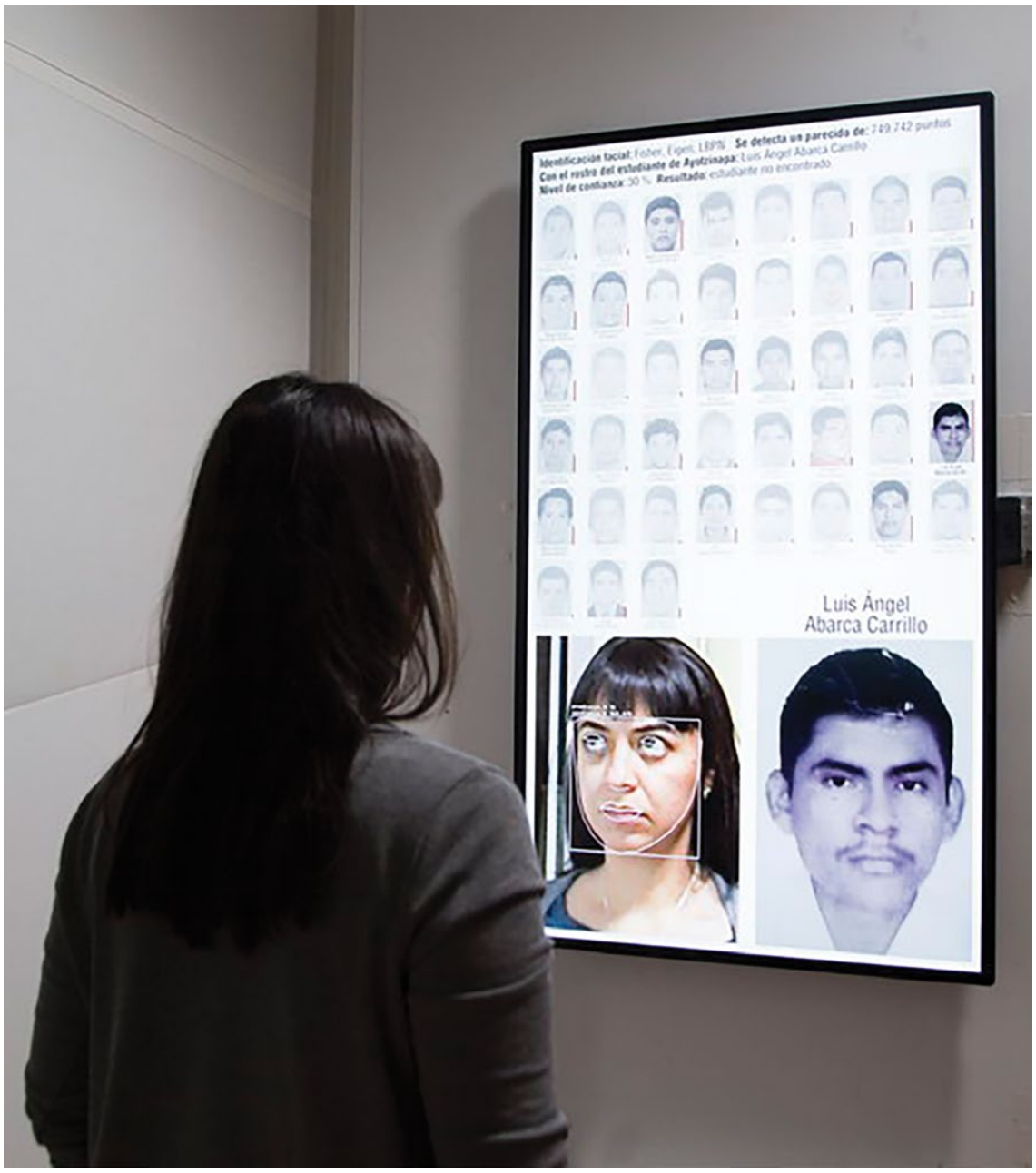

6. Rafael Lozano-Hemmer, Nivel de confianza, 2015. Museo Universitario Arte Contemporáneo, Ciudad de México. Foto cortesía muAC.

Nivel de confianza es un dispositivo intermedia que involucra la alta tecnología, las imágenes de las fotografías análogas de los estudiantes remediadas en imágenes sintéticas y la generación interna de imágenes del cuerpo humano. ${ }^{29}$ $\mathrm{Si}$, como intenté mostrar renglones arriba, en la pieza de Toledo los diferentes

29. Belting, Antropología de la imagen, 25-29. 
papeles desempeñados por las imágenes quieren reintegrar a los 43 en el núcleo social, Nivel de confianza elabora, con las mismas imágenes, sobre nuestros vínculos con ellos en una perspectiva dialógica y reflexiva que involucra la memoria como práctica social.

En la medida en que el público activa la pieza, ésta teje un argumento sobre la búsqueda y posible aparición con vida de los normalistas entre nosotros, en nuestra comunidad, y, debido a que esa búsqueda se basa en el parecido de unos rostros con rasgos indígenas, induce una reflexión sobre un "nosotros" que se proyecta en un sentido nacional. Lozano-Hemmer declaró que como dispositivo para la búsqueda de los estudiantes, "en sentido práctico" el proyecto fue "un fracaso" pues no consiguió la cantidad suficiente de fotografías de los rostros de los normalistas para "entrenar" a los algoritmos, y porque la pieza se puede mostrar sólo en un reducido número de lugares..$^{\circ}$ Entonces afirmó que "el verdadero objetivo de este proyecto aparte de generar dinero para la comunidad afectada y aparte de continuar 'haciendo presentes' a los estudiantes en los medios y en los lugares de exposición, es que el público interiorice la búsqueda, que se encuentren en cierta medida 'en cada uno de nosotros"”. ${ }^{31}$ En esa misma dirección explicó que su propósito fue "ayudar a crear lazos de parentesco y familiaridad con los estudiantes". ${ }^{32}$

Frente a las imágenes sintéticas de los rostros de los estudiantes, ejecutamos una especie de comparecencia en la que los niveles de parecido marcados en la pantalla conducen a la autogeneración de imágenes en una reflexión sobre qué es aquello que nos une o nos separa de esos jóvenes de rasgos indígenas y afromestizos. El dispositivo activa la aparición de imágenes que nos descubren en una relación primaria con ellos, de parecido, y por ello filial. De modo que así, por medio de la atención perceptual y la dedicación emocional, efectuamos un primer reconocimiento: nos detenemos a mirarlos y a mirarnos a nosotros mismos en relación con ellos.

El artista declaró que su proyecto no es un homenaje, entre otras cosas porque "no funciona para preservar la imagen de los estudiantes", pues parte de las imágenes "severas, oficiales y de mala calidad" son las fotos de credencial

30. Cuevas, "Nivel de confianza, entrevista".

3I. Cuevas, "Nivel de confianza, entrevista".

32. Citado en Onia Ávila, "Buscan a los 43 vía electrónica", Excélsior, 27 de abril de 2015, https://antimodular.com/texts/bibliography/articles_level_of_confidence/Excelsior_27Apr20I5.pdf (consultado el 7 de abril de 2019). 
escolar. Por ello, si se le ha de considerar en relación con la memoria debe tomarse en cuenta que:

En este proyecto la memoria no es fosilizada, ni es algo que esté afuera o en el pasado si no $[s i c]$ que es algo que se produce en el instante de la observación y el subsecuente análisis de coincidencias. En esta pieza la memoria no existe sin la presencia del público que la produzca en relación consigo mismo. ${ }^{33}$

Se puede decir, en consecuencia, que Nivel de confianza funciona como contramonumento en el sentido que James A. Young conceptualizó el término, a saber, como un artefacto que activa la participación del espectador en la construcción colectiva del recuerdo. ${ }^{34}$ Efectivamente, el contramonumento pone especial énfasis en el tiempo, que es, de hecho, donde tiene lugar el transcurrir de la memoria, así como en la participación colectiva. Para Young resulta imposible separar la dimensión estética del contramonumento de su dimensión política, pues ésta reside en su responsabilidad cívica, en su capacidad para generar un impacto real en la vida de los ciudadanos: hacia dónde los moviliza, hacia qué conclusiones históricas, hacia qué tipo de comprensión y de acciones en sus propias vidas. ${ }^{35}$

Maurice Halbwachs señaló que los individuos no recuerdan de manera aislada, lo hacen siempre en grupos situados espacial y temporalmente, y de acuerdo con sus intereses y valores en el presente. ${ }^{36}$ De ahí que la memoria es una práctica social. El contramonumento multiplica las memorias, si bien en ese horizonte estético-político arriba señalado, por lo que, en lo que sigue, trazaré algunos pasajes relacionados con la historia de México que estimo pueden activarse de forma afectiva en contacto con Nivel de confianza, o que, en mi caso personal, me vinieron a la mente en interacción con los rostros de los estudiantes y mi nivel de parecido con ellos.

Al tratarse del problema de la desaparición forzada, las relaciones de parecido con los estudiantes guerrerenses, Nivel de confianza nos remite a esa alteridad llamada genéricamente indígena, menospreciada en primera instancia como "no igual" por los conquistadores espańoles, y tiempo despúes, desde el prin-

33. Cuevas, "Nivel de confianza, entrevista".

34. James E. Young, "Cuando las piedras hablan", Puentes, núm. 2 (agosto de 2000): 93.

35. James E. Young, The Texture of Memory. Holocaust, Memorials and Meaning (New Heaven/Londres: Yale University Press, I993), I3.

36. Maurice Halbwachs, Los marcos sociales de la memoria (Barcelona: Anthropos, 2004). 
cipio de la guerra de Independencia, temida por las élites criollas que impusieron en México una formación social basada en la inequidad y la racialización del acceso a la riqueza. Con el paso de la historia, al significante indígena, el primer "enemigo interno" de la nación, se agregaron los significantes "subversivo" y "desaparecible". ${ }^{37}$

Esos dos significantes confluyen con la red de escuelas normales rurales creadas por un régimen posrevolucionario en los años 20 con el propósito de contribuir al desarrollo de las comunidades campesinas con una educación basada en premisas socialistas y a la cual pertenece la "Raúl Isidro Burgos" de Ayotzinapa. Esas escuelas, donde la educación parte de las formas de organización colectivas fundadas en el autogobierno y las luchas campesinas, se convirtieron en centros importantes para la formación de subjetividades disidentes al devenir del proyecto posrevolucionario que pretendió desaparecer al indígena en el mestizo y diseñó el indigenismo como política cultural de asimilación a la nación, al tiempo que conservaba las estructuras de explotación y dominación heredadas del siglo xix. En la escuela "Raúl Isidro Burgos” de Ayotzinapa se formaron Genaro Vázquez Rojas (I93I-I972) y Lucio Cabañas Barrientos (1936-1974), líderes de grupos armados que durante los años setenta intentaron transformar las estructuras que mantenían a los campesinos indígenas, afromexicanos y mestizos en situación de pobreza y marginación extremas. ${ }^{38}$ Los dos fueron asesinados durante la llamada Guerra Sucia, como se conoce a la política de exterminio de movimientos y grupos insurgentes ejecutada por el Estado entre 1969 y 1982 en diferentes regiones del país, pero de manera especialmente cruenta y despiadada en Guerrero. En la recomposición neoliberal de México y en el contexto de "la guerra contra el narcotráfico" de Felipe Calderón, a esa concepción sobre el "subversivo" y "desaparecible" se agregaría la de "miembro del crimen organizado".

En este horizonte, la desaparición de los 43 normalistas no fue un evento aislado, muchos miembros de sus familias habían sido perseguidos, asesinados y desaparecidos o habían sufrido similares violaciones a sus derechos funda-

37. Pozos Barcelata, Le Corps absent, I59. Véase Zigmunt Bauman, Daños colaterales. Desigualdades sociales en la era global (Ciudad de México: Fondo de Cultura Económica, 20II); Zigmunt Bauman, Vidas desperdiciadas. La modernidad y sus parias (Barcelona: Paidós, 2005); Carlos Illades y Teresa Santiago, Estado de guerra. De la guerra sucia a la narcoguerra (Ciudad de México: Era, 20I4).

38. Bertely Busquets, "Breve historia de las escuelas normales", 87. 
mentales. ${ }^{39}$ No obstante, sus denuncias no fueron escuchadas por las autoridades, el único acompañamiento con el que contaron fue el de los organismos de defensa de los derechos humanos. ${ }^{40}$ La atención prestada a los casos de Alejandro Martít ${ }^{41}$ Isabel Miranda de Wallace, ${ }^{42}$ cercanos a los grupos en el poder por su pertenencia a las élites criollas, es una muestra de que en México la práctica de la justicia sigue racializada. Quizá por esa razón Rafael LozanoHemmer declaró que su deseo era que su pieza contribuyera a que la tragedia de Iguala se personalizara de modo que, por ejemplo, "Enrique Peña Nieto se viera ante este espejo biométrico y descubriera qué estudiante tiene los rasgos faciales más parecidos a los de él, para generar empatía, intimidad y una sensación de responsabilidad y parentesco." ${ }^{43}$

Es posible que Nivel de confianza nos remita a las imágenes del pasado y al presente de inequidad y menosprecio prevaleciente en Guerrero y en México, y nos conduzca a recordar a los indígenas zapatistas quienes en los ańos 90 interpelaron a la naturalización del mito del mestizaje, heredado de la revolución de principios del siglo xx, según el cual México es una nación democrática, donde el papel que cada uno ocupa en la sociedad no está definido por la pertenencia a determinadas etnias o grupos sociales.

Si bien Nivel de confianza comparte con Papalotes la solidaridad con las víctimas y la proyección en la esfera pública del delito de la desaparición forzada, también con Sierra León se puede decir que está "conformada técnica y estéticamente de tal manera que contribuya a modificar las condiciones de vulnerabilidad que posibilitan la violación de los derechos humanos". ${ }^{44} \mathrm{Y}$, en ese sentido, puede "contribuir a la imaginación de relaciones sociales y de poder distintas y a imaginar futuros más deseables". ${ }^{45}$

39. Pozos Barcelata, Le Corps absent, $2 \mathrm{II}$.

40. En específico con Tlachinollan, Centro de Derechos Humanos de la Montaña de Guerrero.

4I. Conocido empresario que, en 2008, a raíz del secuestro y asesinato de su hijo menor, Fernando, fundó la organización México sos para contribuir al fortalecimiento de las instituciones de justicia en el país.

42. Derivado del supuesto secuestro y asesinato de su hijo Hugo Alberto Wallace Miranda, el II de julio de 2005 fundó la organización Alto al Secuestro, A.C. Aprobó sin restricciones la política de seguridad de Felipe Calderón, quien en 2010 le otorgó el Premio Nacional de Derechos Humanos. En 2012 fue candidata por el PAN al gobierno del entonces Distrito Federal.

43. Cuevas, "Nivel de confianza, entrevista".

44. Sierra León, "Relaciones entre el arte y los derechos humanos", 89.

45. Sierra León, "Relaciones entre el arte y los derechos humanos", 90. 


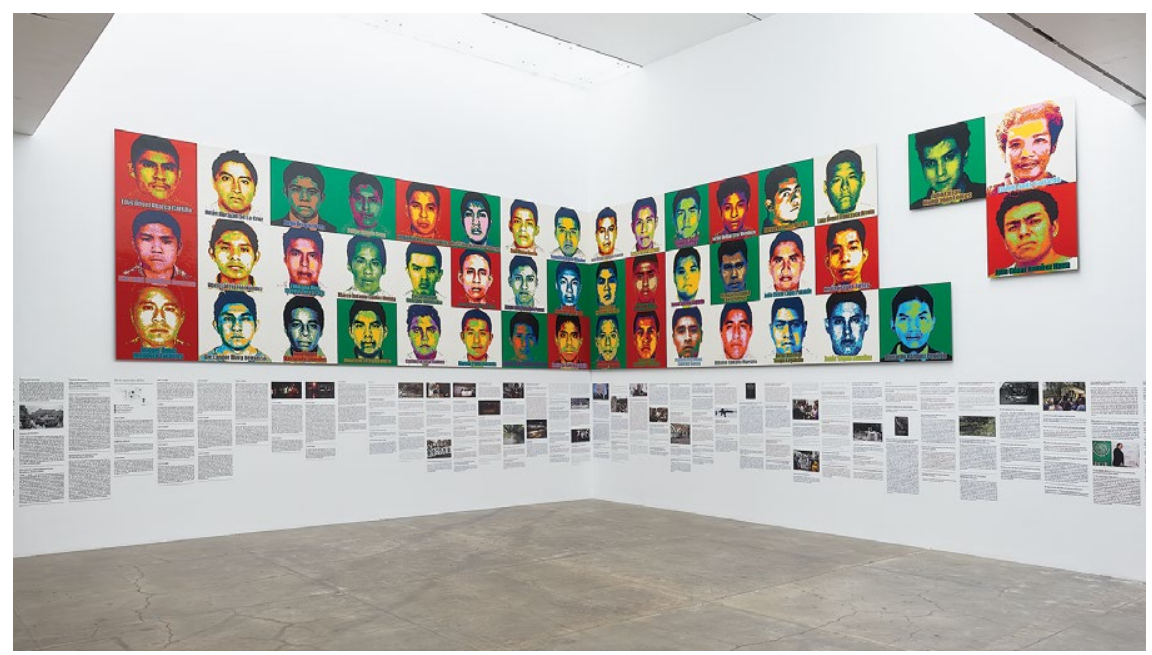

7. Ai Weiwei. Restablecer memorias, Museo Universitario Arte Contemporáneo, Ciudad de México, 2019. Foto: Oliver Santana. Foto cortesía muac.

\section{Retratos de LEGO. Caso Ayotzinapa}

El I3 de abril de 20I9, a casi cinco años de la desaparición de los estudiantes, se inauguró en el Museo Universitario de Arte Contemporáneo de la UNAM la muestra Restablecer memorias, del artista chino Ai Weiwei (fig. 7). Ahí se presentó la pieza Retratos de LEGO. Caso Ayotzinapa, una instalación conformada por un panel monumental con los retratos a color de los 43 estudiantes desaparecidos y los tres asesinados en Iguala realizados con piezas de LEGO, una cronología que inicia en I82I y se detiene en los acontecimientos más importantes del caso entre 20I4 y 2019, y un conjunto de monitores que muestran entrevistas con algunos de los familiares de los estudiantes normalistas, con expertos en derechos humanos que los han acompañado en su lucha y con periodistas que han investigado la tragedia, ${ }^{46} \mathrm{y}$ finalmente, pero no menos importante,

46. Santiago Aguirre Espinoza, subdirector del Centro Prodh; Ximena Antillón Najlis, investigadora en el área de Derechos Humanos y lucha contra la impunidad de Fundar; Francisco Cox, miembro del GIEI; Kate Doyle, analista de la política de Estados Unidos para América Latina en el National Securtiy Archive; John Gibler, escritor y periodista; Témoris Grecko, escritor y periodista, y Ernesto López Portillo, fundador y director ejecutivo en el Instituto para la Seguridad y la Democracia, A. C. 
https://doi.org./10.22201/iie.18703062e.2021.119.2755

una mesa con documentos y libros relacionados con la investigación del caso, las transcripciones de los testimonios de los familiares de los estudiantes registradas en los videos, ${ }^{47}$ investigaciones periodísticas y literatura referente al derecho humanitario (fig. 8). $4^{8}$

Así, la estructura de la instalación se materializa conforme a las estrategias expositivas de muchos de los museos de memoria que se han creado alrededor del mundo a partir de los ańos noventa como resultado de la llamada transición a la democracia, y donde aparentemente las batallas por los derechos humanos en regímenes dictatoriales como Argentina y Chile habrían sido ganadas por las víctimas. Al seguir el guión de esos museos, la instalación de Ai Weiwei monumentaliza y museifica la memoria de los 43 desaparecidos y el sufrimiento de los familiares, esto es, rinde homenaje a los estudiantes, contextualiza los actos criminales perpetrados contra ellos, incluye declaraciones en el género testimonial, así como un pequeño centro de documentación sobre la tragedia.

Durante una visita guiada para las madres y padres de los 43, Cuauhtémoc Medina, curador de la muestra, presentó los retratos de los estudiantes realiza-

47. Forman parte de la película Vivos realizada por Ai Weiwei y estrenada en 2020.

48. Esos materiales son: "Situación de los derechos humanos en México" (Organización de los Estados Americanos); "Doble injusticia. Informe sobre las violaciones de los derechos humanos en la Investigación del Caso Ayotzinapa” (Oficina del Alto Comisionado de las Nacionales Unidas para los Derechos Humanos); "Ayotzinapa Repport. Research and Initial Conclusions of the Disappearances and Homicides of the Normalistas from Ayotzinapa" (Interdisciplinary Group of Independent Experts [GIEI]); "Informe Ayotzinapa II Avances y nuevas conclusiones sobre la investigación, búsqueda y atención a las víctimas" (Grupo Interdisciplinario de Expertos Independientes [GIEI]); "Dictamen sobre el Basurero de Cocula, febrero, 20I6" (Equipo Argentino de Antropología Forense); "Informe del Mecanismo Especial de Seguimiento al Asunto Ayotzinapa" (Comisión Interamericana de Derechos Humanos y Organización de los Estados Americanos); "Situation Report. Special Follow-up Mecanism to the Ayotzinapa Case of the IACHR" (Interamercian Comission of Human Rights); "I couldn't even imagine that they would kill us. An oral history of the attacks against the students of Ayotzinapa" y "Una historia oral de la infamia. Los ataques contra los normalistas de Ayotzinapa" (John Gibler); "Faces of Ayotzinapa: A Cronicle of Injusticie" (Tryno Maldonado); "La verdadera noche de Iguala. La historia que el gobierno trató de ocultar" y "A Masacre in Mexico. The True Story Behind the Missing Forty-Three Students" (Anabel Hernández); "Ayotzinapa. La travesía de las tortugas. La vida de los normalistas antes del 26 de septiembre de 20I4" (Ediciones Proceso); "Mentira histórica. Estado de impunidad, impunidad del Estado" (Témoris Grecko); "El tiempo de Ayotzinapa" (Carlos Marín Beristain); "Ayotzinapa. Horas eternas" (Paula Mónaco Felipe); "Yo solo quería que amaneciera'. Impacto psicológico del caso Ayotzinapa. Entrevistas relacionadas con el caso Ayotzinapa 25.03.2018-08.10.2018" e "Interwiews Relating to the Ayotzinapa Case" (Ai Weiwei Studio); y fotocopias de documentos legales para el recurso de revisión del caso. 


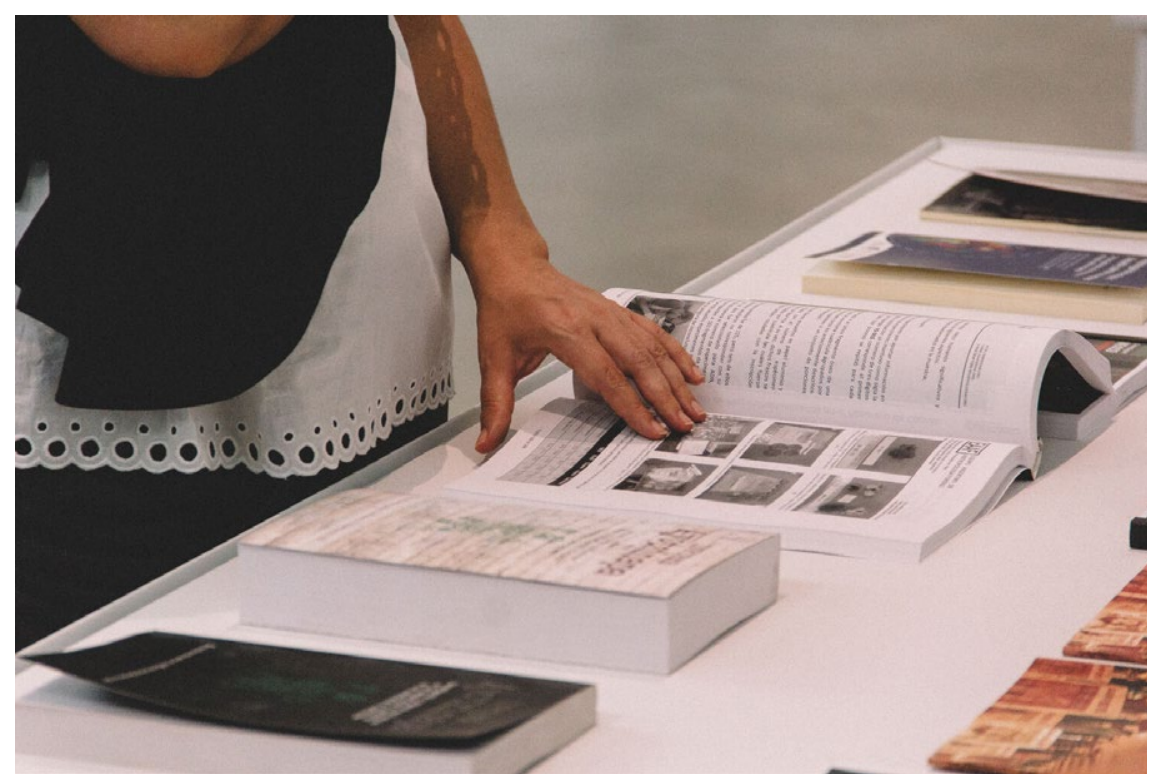

8. Ai Weiwei. Restablecer memorias, Museo Universitario Arte Contemporáneo, Ciudad de México, 2019. Foto cortesía MUAC.

dos en LEGo como un "homenaje" en forma de "mural", 49 es decir, como un reconocimiento público a los estudiantes desaparecidos en un memorial. Y explicó que: "Esta pieza tiene dos propósitos: por un lado, el de recordar y hacer presentes a los que no están con nosotros, pero también hacer que el público que viene al museo sepa que ha habido una falla, una ofensa, una total falta de responsabilidad por parte de las autoridades" ${ }^{\circ}$ en el tratamiento judicial del caso. Por su parte, el sufrimiento de los familiares se exhibe para mostrar que "la negligencia que su destino ha encontrado de parte del gobierno y la sociedad se ha multiplicado en muchos otros destinos y víctimas". ${ }^{\text {.I }}$ Aunque el curador no explica la inclusión de la mesa con libros y documentos cuyo contenido ubi-

49. Citado en Gaceta UNAM, "Familiares de los 43 desaparecidos de Ayotzinapa visitan el MUAC", 6 de junio de 2019 .

50. Citado en Gaceta UNAM, "Familiares de los 43 desaparecidos de Ayotzinapa visitan el MUAC".

5I. Cuauhtémoc Medina, “Algo bello ya no está. Sobre el quebranto de la memoria”, en Ai Weiwei. Restablecer memorias (Ciudad de México: Museo Universitario de Arte Contemporáneo, unAm/Museo de Arte Contemporáneo de Monterrey), i6. 


\section{BLANCA GUTIÉRREZ GALINDO}

ca la tragedia de Iguala en la perspectiva de los derechos humanos, se puede decir que esos materiales vienen a completar las dimensiones narrativa y argumentativa de la instalación en los marcos de sentido producidos por los museos de memoria y derechos humanos.

Retratos de LEGO. Caso Ayotzinapa es una obra que busca lo que Sierra León llama "efecto sensibilizador", en donde "la obra de arte es una herramienta cognitiva, didáctica, emocional o comunicativa, que le permite al espectador u observador aproximarse a un universo que le es desconocido". ${ }^{52}$ Éste es el caso de la instalación de Ai Weiwei que constituye un caso representativo de su activismo, ${ }^{53}$ y es coherente con su programa artístico en favor de los derechos humanos. Medina reporta que entre 2016 y 2017 el artista visitó México para planificar una exposición que se presentaría en el Museo de Arte Contemporáneo de la UNAM, y que en ese momento decidió hacer una pieza sobre la realidad mexicana al interesarse por la crisis de derechos humanos en el país. ${ }^{54}$ También señala que con ese motivo visitó el Centro de Derechos Humanos "Miguel Agustín Pro Juárez"ss de la Ciudad de México y concibió la instalación y la película Vivos al coincidir por casualidad con algunos de los pares de los estudiantes normalistas, con quienes mantuvo una breve conversación. María Luisa Aguilar Rodríguez, ${ }^{56}$ defensora de los derechos humanos de ese Centro, y quien ha acompañado en su lucha a los familiares de los normalistas desparecidos, señaló la importancia que para los defensores de derechos humanos reviste el interés de Ai Weiwei por el caso Ayotzinapa debido a que él es "activista, víctima, sobreviviente y artista. El paquete completo". ${ }^{77}$

52. Sierra León, "Relaciones entre el arte y los derechos humanos", 90.

53. Véase Sarah Thornton, 33 artistas en 3 actos (Buenos Aires: Edahsa, 2015).

54. Medina, "Algo bello ya no está", I5.

55. Junto con Servicios y Asesoría para la Paz, A. C. (Serapaz), Centro de Análisis e Investigación Fundar y Tlachinollan Centro de Derechos Humanos de la Montaña de Guerrero, el Centro Prodh forma parte del equipo de la sociedad civil que acompaña a las familias de los estudiantes desaparecidos desde los días de la denuncia de su desaparición. Véase María Luisa Aguilar Rodríguez, "Ayotzinapa: defender la dignidad", en Ai Weiwei. Restablecer memorias, 238-245.

56. En una entrevista con el artista y con Cuauhtémoc Medina celebrada el día anterior a la inauguración de la muestra, y filmada y transmitida por TV unAM dentro de la serie Pensadores Contemporáneos.

57. Ai Weiwei, Cuauhtémoc Medina y María Luisa Aguilar, "Conversatorio con Ai Weiwei”, muac, TV unam, Pensadores contemporáneos, I2 de abril de 20I9,en https://culturaendirecto. unam.mx/video/ai-weiwei-en-pensadores-contemporaneos/ (consultado el to de abril de 2020). 
Sin ninguna clase de ironía, esa última declaración señala las articulaciones entre activismo por los derechos humanos y medios de comunicación, y el papel que en ellas desempeñan en la actualidad neoliberal la mercadotecnia y la publicidad. Se trata, en efecto, de un activismo no violento y profesionalizado que en el mundo globalizado opera como poder blando (soft power) $)^{58}$ por medio de las celebridades y personajes de renombre en los mundos de la cultura y el espectáculo.

Si bien las movilizaciones que siguieron a la denuncia nacional e internacional de la desaparición de los estudiantes contaron con la participación de redes nacionales e internacionales de activistas organizadas en las acciones globales por Ayotzinapa, que dieron la vuelta al mundo a través de las redes sociales y los medios de comunicación tradicionales, ${ }^{59}$ y a pesar de la adhesión de artistas como Marcelo Brodsky, o los mismos Toledo y Lozano-Hemmer, colectivos como Forensic Architecture o cantantes como Sting, hasta el momento de la exposición de Ai Weiwei en México, el caso no había penetrado los más importantes circuitos globales de la cultura y el arte contemporáneo. Además, a casi cinco ańos de la tragedia, el apoyo de la sociedad a las movilizaciones de los familiares había disminuido, igual que su visibilidad mediática. De tal suerte, la atención prestada al caso por el artista lo cubre con su propio prestigio y amplifica su importancia. Respecto al hilo conductor de este texto, que es el papel que desempeñan las imágenes de los rostros de los normalistas en estas piezas, enseguida anotaré algunos comentarios sobre las operaciones con las cuales el artista chino introduce y proyecta esas imágenes en el mundo de la cultura global.

En primer lugar, importa señalar que para los retratos de los estudiantes el artista eligió las convenciones de estética del arte pop del primer Andy Warhol, utilizadas anteriormente por él mismo en las piezas Trace (2014) y en Circle of Animals (20I0). Trace se creó por primera vez como parte de una retrospectiva celebrada en 20I4, en la ex cárcel de la isla Alcatraz, en San Francisco, convertida en espacio de arte contemporáneo. La experiencia como preso de conciencia en China en 2011 lo impulsó a trabajar en esta retrospectiva con

58. Tomo esta idea de José Antonio Moreno Chávez, Curso Activismo y Derechos Humanos. Historia, evolución y cultura activista desde 1960 hasta la fecha. Museo de Memoria y Tolerancia. Centro Educativo Truper. Curso presencial, septiembre de 2019. Sobre la idea de soft power véase Joseph S. Nye Jr., "El poder blando y la política exterior americana”, Relaciones Internacionales, núm. I4 (2010): II7-I40.

59. Pozos Barcelata, Le Corps absent, 435 . 
Amnistía Internacional y otros grupos de defensores de derechos humanos en la recopilación de las historias de 176 activistas y defensores de la libertad de expresión de 33 países, que perdieron su libertad debido a sus creencias. En aquella ocasión la empresa $\mathrm{LEGO}^{60}$ se negó a cooperar con el artista porque no quería que sus productos se usaran "con fines políticos", por lo que los retratos se realizaron con donaciones. En Trace se incluyeron los retratos de personalidades muy conocidas como Luther King, Nelson Mandela, Liu Xiaobo, Edward Snowden y Chelsea Manning, y otros no tan conocidos como John Kiriakou y Shaker Aamer. ${ }^{61}$

Los retratos en LEGO de los 43 estudiantes de Ayotzinapa guardan una relación de semejanza visual con las imágenes de celebridades como Marilyn Monroe y Jackie Kennedy, realizadas por Warhol en los años setenta, como señala Cuauhtémoc Medina, quien retoma el argumento del historiador Thomas Crow, ${ }^{62}$ para quien esas imágenes indican la inadecuación entre la estética de la mercancía y la imagen del sufrimiento y la muerte producida y diseminada por medios de reproducción masiva, lo que haría de Warhol un artista empático y comprometido, ${ }^{63} \mathrm{y}$ un practicante de cierta "pintura de historia" ${ }^{64}$ En una entrevista con el propio Medina, Ai Weiwei explicó que cuando, con motivo de la exposición en San Francisco, recibió las fotografías de Amnistía Internacional muchos prisioneros no tenían una fotografía clara y que en ocasiones sólo había una imagen de un periódico viejo y por esa razón se le ocurrió "producirlos con LEGo para renderizar cada imagen en una calidad similar. Son pixeles y fabricados industrialmente. El color de los LEGOS es consistente. La gente lo entiende perfectamente". Y agregó que algo similar sucedió en el caso de los 43 ya que "muchas de sus fotografías no son aceptables. Dado que provienen de familias pobres, muchas de las fotografías no son de alta calidad". ${ }^{65}$

60. LEGO es una empresa y marca de juguetes danesa mundialmente conocida por sus bloques de plástico interconectables. Fundada en 1932 por Ole Kirk Christiansen, su nombre es abreviatura de dos palabras danesas leg godt (“jugar bien”).

6I. Roger Catlin, "Ai Weiwei Depicts the Brutality of Authoritarianism in an Unusual Medium-Legos", Smithsonian Magazine, 20I7, en https://www.smithsonianmag.com/smithsonian-institution/ai-weiwei-depicts-brutality-authoritarianism-unusual-medium-legos-I80964006/ (consultado el Io d enero de 2020).

62. Thomas Crow, El arte moderno en la cultura de lo cotidiano (Madrid: Akal, 2002), 55-74.

63. Douglas Crimp, Posiciones criticas. Ensayos sobre la politica de arte e identidad (Madrid: Akal, 2005), $\mathrm{i} 68$.

64. Crow, El arte moderno, 65.

65. Medina, "Algo bello ya no está", II8. 
De acuerdo con los argumentos de Crow, quiero reflexionar sobre la condición de intercambiabilidad del millón de piezas de LEGo con las cuales los estudiantes de la Facultad de Artes y Diseño y la Facultad de Arquitectura de la UNAM crearon las imágenes que habrían permitido satisfacer la necesidad declarada por el artista de mejorar la calidad de las imágenes de los rostros plasmados en las fotografías de los normalistas. Si en la pieza de Toledo el problema fundamental es el de la imagen de los ausentes y en la de Lozano-Hemmer el de la generación de imágenes del recuerdo y la multiplicación de memorias, en la de Ai Weiwei el problema son los medios del arte a la manera en que lo fueron para Warhol, es decir, mostrar que en la sociedad del consumo y el espectáculo experimentamos el mundo por medio de las imágenes y que su condición artística es un resultado institucional. ${ }^{66}$ En la medida en que las piezas que conforman los retratos son intercambiables se pueden pensar en la idea de "fotografías hechas a mano", con la que el mismo Thomas $\mathrm{Crow}^{67}$ interpretó imágenes de Warhol como Do It Yourself, que el artista produjo en 1962 con base en los kit comerciales para artistas amateurs y en los cuales esos aspirantes a artistas debían someterse a una serie de ejercicios imitando composiciones y efectos visuales ya hechos. Crow explica que son "fotografías hechas a mano" porque a menudo las imágenes seleccionadas por los pintores autodidactas para calcarlas y pintarlas laboriosamente provenían de las fotografías de lo que en aquella época era el genuino underground del arte: "estrellas pop, atletas, pin ups, niños, coches y animales de compañía", ${ }^{68}$ es decir, las imágenes con las cuales se produce al sujeto de la masa, que Warhol habría de elevar al estatuto de imágenes artísticas gracias a estos y otros procedimientos semejantes.

De esa manera, con las piezas intercambiables de LEGO se cumple la aspiración del artista chino en el sentido de la mejora de la calidad de las imágenes de los estudiantes y del carácter democrático de su hechura y "comprensión”. Así a pesar de que cada rostro está singularizado por el nombre del estudiante, ningún retrato es mejor que otro, todos están hechos con los mismos colores, todos son el mismo retrato, ${ }^{69}$ todos son reconocibles, igual que las imágenes de la publicidad.

La intercambiabilidad de las piezas reside en su carácter serial, en su producción industrial — como el mismo Ai Weiwei señala—, de modo que el uso

66. Hans Belting, Le Chef d'ouvre invisible (Nimes: Éditions Jaqueline Chambon, 2003), 492.

67. Crow, El arte moderno, IO4.

68. Crow, El arte moderno, Io6.

69. Belting, Le Chef d'ouvre invisible, 494. 
https://doi.org./10.22201/iie.18703062e.2021.119.2755

IOO

BLANCA GUTIÉRREZ GALINDO

de LEGO para facturar los retratos de los estudiantes desaparecidos es significativo en más de un sentido. No sólo muestra que cualquiera puede hacer o identificar esas imágenes, evidencia también el carácter intercambiable de los individuos en la sociedad de masas, de modo que los retratos podrían referirse a la posibilidad de que cualquiera de nosotros podría ser asesinado o desaparecido. Pero esta idea es engañosa, ya que la desaparición de los estudiantes normalistas ocurrió en Guerrero, precisamente en razón de su pertenencia a unas escuelas con tradición socialista y a unas comunidades que desde décadas habitan un territorio de muerte, esto es, por su condición de "desaparecibles". Así, la intercambiabilidad representa una operación de igualación o nivelación que está también presente en la forma en la cual Ai Weiwei equipara visualmente a los tres estudiantes asesinados (uno de ellos Julio César Mondragón, cuyo cuerpo abandonado en un baldío con el rostro arrancado fue un mensaje de los criminales), con las de los 43 desaparecidos, e igualmente nivela visualmente los rostros de los estudiantes con los de los 176 prisioneros de Trace. Esa operación también está presente en el formato de las entrevistas a los padres y madres de los estudiantes, y en el tamaño y ubicación espacial de las pantallas exhibidas en el museo. Pareciera que, de ese modo, el artista quisiera extenuar las imágenes de los 43 estudiantess como imagen publicitaria, aspecto que constituye una de las dimensiones de Retratos de LEGO y forma parte de su efecto sensibilizador.

Así, los 46 jóvenes de la Escuela Normal de Ayotzinapa entran en un inmenso salón trasnacional de víctimas agrupadas bajo el gran paraguas de la oposición al autoritarismo y la injusticia. El título Retratos de LEGO y el subtítulo Caso Ayotzinapa muestra que en el futuro ese salón puede ser ampliado. Todas esas operaciones de igualación que hacen identificables a las imágenes encubren una decisión que es política: la de omitir la comprensión de las particularidades del capitalismo criminal y los diferentes momentos y modalidades de su articulación con los Estados en el planeta. Así es que, si bien los retratos de LEGO amplifican la visibilidad del caso, también encubren su singularidad histórica que reside en que los estudiantes fueron desaparecidos y asesinados por su origen y condición.

$Y$ eso es posible porque, si bien es verdad que el carácter conmemorativo de los retratos de los normalistas los vincula con las imágenes pop creadas por el primer Warhol, también hay que anotar que Ai Weiwei procede en forma inversa al artista estadounidense. En efecto, a diferencia de éste, que para comunicar su carácter funeral sometió las fotografías en blanco y negro de Marilyn a la borradura y el barrido, Ai Weiwei, en su afán por mejorar la calidad 
de las fotografías de los estudiantes y dotarlas de un look post-pop, procede a la aniquilación del descoloramiento y las borraduras producidas por la baja calidad de las impresiones, pero también por el desgaste generado por los usos a los que han sido sometidas, es decir a las huellas de una materialidad que informa los contextos concretos de vida, sufrimiento y lucha cotidiana de quienes sobreviven en los territorios de la miseria, la marginación y la desigualdad. Por ello el procedimiento de Ai Weiwei es más bien semejante al llevado a cabo en la serie La última cena, en la cual Warhol confeccionó una imagen más "real" que la de la pintura original de Leonardo, en ese momento casi borrada por completo. ${ }^{70}$

Retratos de LEGO. Caso Ayotzinapa pone en evidencia una especie de paradoja que consiste en que, si bien constituye un reconocimiento público a los estudiantes y un acto de memoria con un amplio efecto sensibilizador, porque sin duda contribuye a mostrar y evidenciar los daños causados por la violencia y la impunidad que han marcado el caso de los 43 estudiantes, también obra una solidificación de las formas del recuerdo en esas imágenes "más reales". La instalación elabora retratos para una memoria ready made y, en esa medida, despoja de agencia a las imágenes, cuyas propiedades materiales son en sí mismas significantes porque en ellas confluyen afectos y contextos que mueven a la acción individual y colectiva. En ese sentido, una imagen contrastante y conmovedora es la de las madres y los padres de los estudiantes en la exposición del artista, portando las imágenes descoloridas, pero "vivas" de sus hijos, algunas decoradas con motivos florales y vegetales (fig. 9); imágenes que, como indiqué más arriba, "son" los estudiantes.

\section{Reflexión final}

La desaparición de los estudiantes de Ayotzinapa y la rápida denuncia de los hechos por parte de organismos de derechos humanos, haciendo un llamamiento internacional a reaccionar ante el caso, hizo posible que de manera inmediata, el 3 de octubre de 20I4, la Oficina para el Alto Comisionado de Naciones Unidas por los Derechos Humanos calificara el caso como "uno de los sucesos más terribles de los tiempos recientes". ${ }^{71}$ Después vendrían las movilizacio-

70. Belting, Le Chef d'ouvre invisible, 497.

7I. Pozos Barcelata, Le Corps absent, 428. 


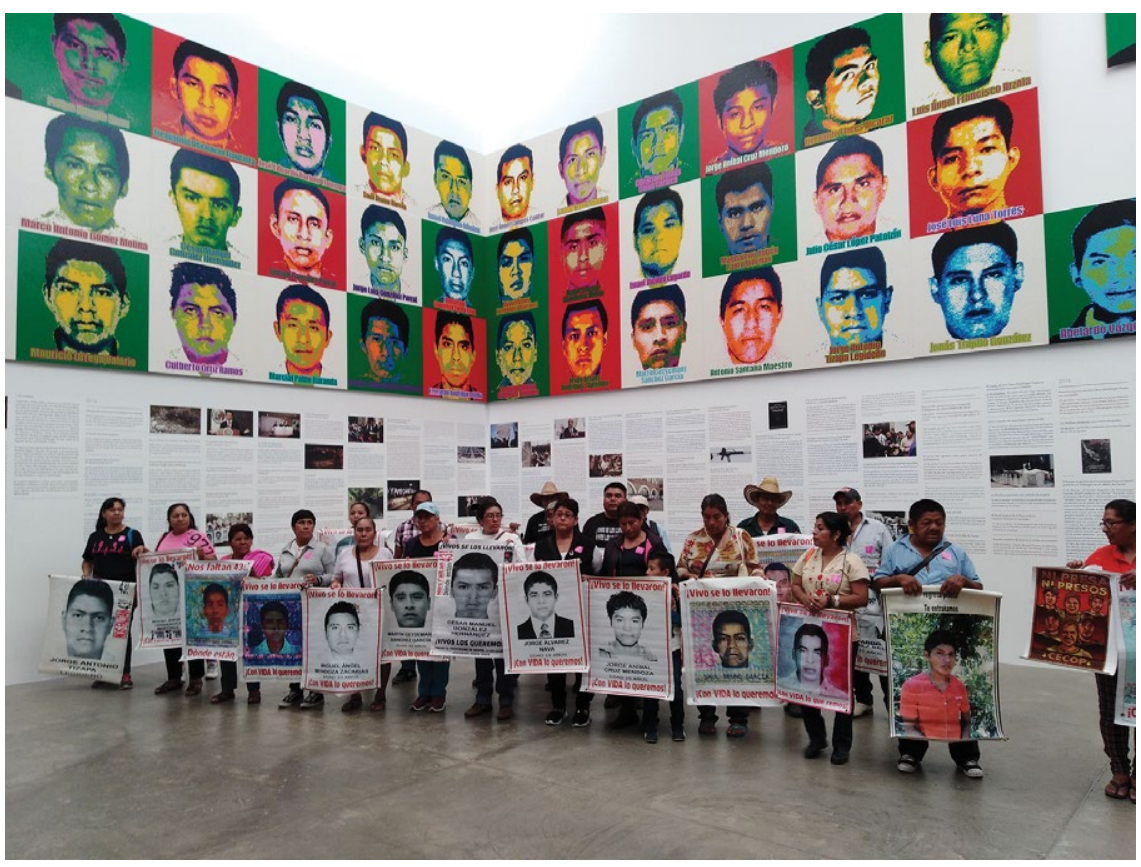

9. Nicolás Gamboa, Madres y padres de los estudiantes normalistas delante de Retratos de LEGO de Ai Weiwei, Museo Universitario Arte Contemporáneo, Ciudad de México, 20I9. Tomada de https://www.gaceta.unam.mx/padres-y-madres-de-ayotzinapa-visitan-el-muac/

nes en todo el país y en el extranjero que, por su magnitud y multiplicidad, no tienen precedente en la historia reciente..$^{72}$ De esa manera, la tragedia de Iguala hizo evidente la crisis de derechos humanos en el país y suscitó la preocupación de numerosos artistas quienes se unieron a las movilizaciones y comenzaron a tematizar los hechos.

Las tres piezas analizadas en este texto pueden comprenderse mediante la noción de litigio artístico, acuñada por Yolanda Sierra León, en la medida en que, desde diferentes perspectivas, dignifican la memoria de los estudiantes y contribuyen a mantener la lucha de los familiares por una investigación justa que dé con el paradero de los jóvenes y castigue a los culpables. Se trata de piezas realizadas de manera independiente que median las relaciones entre víctimas y afectados, y entre víctimas y sociedad en diferentes niveles.

\section{Pozos Barcelata, Le Corps absent, 434.}


Así, Papalotes es un gesto de reconocimiento que se despliega en diferentes versiones y perspectivas y utiliza las imágenes de los rostros de los estudiantes para reintegrarlos a la comunidad mediante rituales funerarios solidarizándose, de ese modo, con los afectados al poner a su disposición un artefacto para el procesamiento del duelo.

En cuanto contramonumento, Nivel de confianza se propone como mediación entre las víctimas y los diversos grupos sociales pues activa la generación de los múltiples recuerdos e imágenes de la memoria individual y colectiva que nos ponen en una relación intersubjetiva con los estudiantes quienes, por su origen y condición, fueron desaparecidos y asesinados, y en esa medida puede contribuir a imaginar otras relaciones sociales en nuestro país.

Por último. Retratos de LEGO. Caso Ayotzinapa constituye una muestra ejemplar del efecto sensibilizador en la medida en que utiliza la militancia en la defensa de los derechos humanos en la actualidad neoliberal para promover, en un ámbito mediático global sin precedentes, la estima social de los 46 estudiantes de Ayotzinapa y la solidaridad con sus familiares por medio de la monumentalización y museificación de su memoria y del sufrimiento de sus familiares.

Sierra León plantea el "efecto transformador" como par conceptual del efecto sensibilizador, en el que el primero, además de incluir los elementos propios del segundo, "permite la modificación de las condiciones de vulnerabilidad que facilitan la violación de los derechos humanos. No basta, entonces, con incorporar el tema, es preciso que el artista se sumerja en las condiciones sociales de las víctimas, de los desprotegidos, y contribuya decididamente a conformar grupos de resistencia política donde el arte es un medio para lograr ese propósito". ${ }^{73}$ Resulta evidente que ninguna de las piezas analizadas aquí posee ese efecto. No obstante, como he tratado de mostrar, las tres introducen en el debate estético mexicano la defensa de los derechos humanos, y, en consecuencia, nos permiten reflexionar sobre las articulaciones ente arte y política en una nueva dimensión: la de la utilidad del arte en los procesos relacionados con las acciones y procesos necesarios a la reparación simbólica de los daños resultantes de la violencia política, la injusticia y la impunidad. \&

73. Sierra León, "Relaciones entre el arte y los derechos humanos", 93.

N.B. Este artículo se realizó con el apoyo del Programa de Apoyos para la Superación del Personal Académico (PASPA) de la Dirección General de Asuntos del Personal Académico (DGAPA), de la Universidad Nacional Autónoma de México (UnAM) durante los meses de octubre y noviembre de 2019 y enero de 2020 . 